\title{
The Role of Thiol-Disulfide Hemostasis in Predicting Renal İnjury After Coronary Artery Bypass Graft Surgery
}

\section{Koroner Arter Bypass Greft Ameliyatı Sonrası Böbrek Hasarını Öngörmede Tiyol-Disülfıd Hemostazın Rolü}

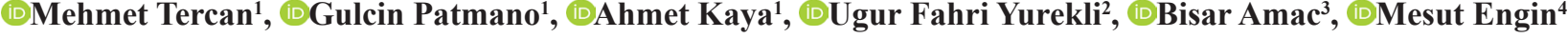 \\ 'Department of Anesthesiology and Reanimation,University of Health Science Mehmet Akif Inan Research and Training Hospital, Sanliurfa, Turkey \\ ${ }^{2}$ Department of Biochemistry, University of Health Science Mehmet Akif Inan Research and Training Hospital, Sanliurfa, Turkey \\ ${ }^{3}$ Department of Perfusion, University of Health Science Mehmet Akif Inan Research and Training Hospital, Sanliurfa, Turkey \\ ${ }^{4}$ Department of Cardiovascular Surgery, University of Health Science Mehmet Akif Inan Research and Training Hospital, Sanliurfa, Turkey
}

Copyright (c) 2021 by authors and Medical Records Publishing Inc.

\begin{abstract}
Aim: Elnflammation andoxidative stres play an active role in renal injury that develops after open heart operations as in many diseases. There is a balance between oxidants and antioxidant defense mechanisms, and in the morbidity of cardiac surgery patients, this balance is thought to change depending on many factors.

Materials and Methods: 76 patients scheduled for coronary artery bypass graft surgery were included in the study. Demographic and operation information of the patients were recorded. In addition to routine blood parameters, blood samples were taken forthiol / disulfid hemostasis parameters. Patients who did not develop acut kidney injury (AKI) after the operation were recorded as Group 1 and those who developed register as Group 2.

Results: Postoperative AKI developed in $19(25 \%)$ patients included in the study. When the thiol-disulfide hemostasis parameter values obtained from the blood sample taken within the first 2 hours after the introduction of intensive care after the operation of the patients, there was no difference between the two groups in terms of native thiol, total thiol, disulfide / native thiol and native thiol / total thiol values. In Group 2, disufide and disulfide / total thiol values were significantly higher $(P=0.018, P=0.009)$.

Conclusion: We believe that the values of disulfide and disulfide / total thiol ratio, which are among the parameters of thiol-disulfide hemostasis, in the postoperative period may be predictors for AKI.
\end{abstract}

Keywords: Oxidative stres parameters; thiol levels; disulfide; kidney injury; cardiac surgery

$\mathrm{Oz}$

Amaç: İnflamasyon ve oksidatif stres, birçok hastalıkta olduğu gibi açık kalp ameliyatları sonrası gelişen böbrek hasarında da aktif rol oynamaktadır. Oksidanlar ve antioksidan savunma mekanizmaları arasında bir denge vardır ve kalp cerrahisi hastalarının morbiditesinde bu dengenin birçok faktöre bağlı olarak değiştiği düşünülmektedir.

Materyal ve Metod: Koroner arter baypas cerrahisi planlanan 76 hasta çalışmaya dahil edildi. Hastaların demografık ve operasyon bilgileri kaydedildi. Rutin kan parametrelerine ek olarak tiyol / disülfıd hemostaz parametreleri için kan örnekleri alındı. Ameliyat sonrası akut böbrek hasarı (AKI) gelişmeyen hastalar Grup 1, gelişen hastalar Grup 2 olarak kaydedildi.

Bulgular: Çalışmaya dahil edilen 19 (\% 25) hastada postoperatif AKI gelişti. Hastaların operasyon sonrası yoğun bakıma alınmasından sonraki ilk 2 saat içinde alınan kan örneğinden elde edilen tiyol-disülfıd hemostaz parametre değerleri incelendiğinde, iki grup arasında nativ tiyol, total tiyol, disülfid / nativ tiyol ve nativ tiyol / total tiyol değerleri açısından fark yoktu. Grup 2'de disülfid ve disülfıd / total tiyol değerleri anlamlı olarak yüksekti $(P=0.018, P=0.009)$.

Sonuç: Postoperatif dönemde tiyol-disülfid hemostaz parametreleri arasında yer alan disülfıd ve disülfıd / total tiyol oran değerlerinin AKI için öngörücü olabileceğine inanıyoruz.

Anahtar Kelimeler. Oksidatif stres parametreleri; tiyol seviyeleri; disülfid; böbrek hasarı; kalp cerrahisi

Geliş Tarihi / Received: 01.09.2020 Kabul Tarihi / Accepted: 20.11.2020

Sorumlu Yazar /Corresponding Author. Bisar Amac, Department of Perfusion, University of Health Science

Mehmet Akif Inan Research and Training Hospital, Sanliurfa, Turkey

Email: amacbisar@gmail.com 


\section{INTRODUCTION}

Open heart surgeries are common operations in many heart diseases, such as coronary and heart valve diseases. The use of the cardio pulmonary bypass (CPB) system in these surgeries increases technical success. However, as a result of using this system, the blood comes into contact with extravascular surfaces, thus inflammatory pathways are activated. This can lead to various complications such as cerebrovascular accident, mesenteric ischemia, renal failure and mortality.

Although acute kidney injury (AKI) is monitored at a rate of $5-30 \%$ after cardiac surgery, the need for renal replacement may occur in $1-2 \%$ of these patients (1). Many factors play a role in the emergence of this condition, such as prolonged perfusion times, increased age, presence of preoperative renal insufficiency and increased blood product transfusion $(2,3)$. Inflammation and oxidative stres play an active role in renal injury that develops after open heart operations, as in many diseases. Various inflammatory markers in this area have been investigated in predicting postoperative $\mathrm{AKI}(4,5)$.

In recent years, it has been revealed that thiol-disulfide hemostasis can be an important biomarker of oxidative stres (6). Thiol is a compound containing sulfhydryl group (-SH), which plays an important role in preventing oxidative stress in cells. Thiol groups are converted to reversible disulfide structures by oxidant radicals. These disulfide structures can be reduced back to thiol groups, there by maintaining thiol-disulfide homeostasis, which is important for many cellular processes, such as the antioxidant defense system. Thiol-disulfide homeostasis can indirectly reflect the oxidative stres state of the organism. There is a balance between oxidants and antioxidant defense mechanisms and it is thought that this balance varies depending on many factors in the morbidity of cardiac surgery patients (7).

In this study, we aimed to investigate the role of thioldisulfide hemostasis parameters in predicting $A K I$ after coronary artery bypass graft (CABG) surgery accompanied by CPB.

\section{MATERIAL AND METHODS}

\section{Study Design}

In this prospective study, CABG patients with elective CPB in our clinic between March 15, 2019 and November 15, 2019 were included. The study started after the approval of the local ethics committee (HRU / 25.02.2019). Patients with emergency operations, those with creatinine $>1.5 \mathrm{mg} /$ $\mathrm{dl}$ in the preoperative period, who underwent percutaneous coronary angiographic intervention in the last 24 hours, who had systemic inflammatory disease, reoperations and streorid treatment were excluded from the study. As a result of exclusion criteria, 76 consecutive patients were included in the study.

Demographic and preoperative features (Age gender, body mass index (BMI), hyperlipidemia, hypertension (HT), diabetes mellitus (DM), chronic obstructive pulmonary disease (COPD) and current medical treatments (acetyl salicylic acid, angiotensin receptor blocker therapy) smoking, routine blood parameters etc.), as well as operative (cross clamp times, total perfusion times, graft counts, total amount of blood product used) and postoperative data (routine blood parameters, renal injury status as a result of creatinine measurement, total blood product usage, thorax tube drainage amounts, hospital and intensive care hospitalization times etc.) were recorded. In addition, for the thiol-dylsulfide hemostasis parameters, which is the main hypothesis of the study, blood samples were taken twice, after anesthesia induction before surgery and 2 hours after being taken to the postoperative intensive care unit. Patients who did not develop AKI after the operation were recorded as Group 1 and those who developed register as Group 2.

\section{Anaesthesia Management}

After routine anesthesia induction, the patients were intubated and ventilated with tidal volume of $6-8 \mathrm{ml} / \mathrm{kg}$, end-tidal carbon dioxide (ETCO2) $30-40 \mathrm{mmHg}$ in $50 \%$ 02-air mixture. Median sternotomy incision was applied to all patients. Vasopressor or vasodilator agents were given when mean arterial pressure (MAP) values were $\pm 20 \%$ from basal values during the CPB period. MAP values were adjusted to be in the range of $65-70 \mathrm{mmHg}$. In the nonpulsatile KPB period, $2.4 \mathrm{~L} / \mathrm{min} / \mathrm{m} 2$ flow was provided according to the body surface area. In this period, MAP values were adjusted to be $55-65 \mathrm{mmHg}$. ACT (activated clotting time) values were checked with 30-minute periodic measurements until the CPB was discontinued and the cannulas were removed. At the end of the operation, controlled extubation was planned by taking all patients to mechanical ventilation support in the intubated intensive care unit.

\section{Identification of Postoperative RenalInjury}

Renal injury status after the operation was determined according to the criteria of Acute Kidney Injury Network (AKIN) (8). This staging is done as follows:

Stage 1: 1.5-2 times increase or $>0,3 \mathrm{mg} / \mathrm{dl}$ increase compared to basal value

\section{Stage 2: 2-3 times increase in creatinine value}

Stage 3: Creatinine increase more than 3 times or $4 \mathrm{mg} / \mathrm{dl}$ increase or renal replacement therapy is required

Patients who met the above-mentioned criteria in the postoperative hospital were accepted as the group of patients developing AKI. This situation was accepted as the primary end point of the study.

\section{Analysis of blood parameters}

Routine blood parameters of the patients were evaluated from the blood samples taken from antecubital veins before the operation. Complete blood countand biochemical parameters were measured with automatic analyzers. Thiol-dylsulfide hemostasis parameters 
were studied from the blood samples taken before the operation ( $\mathrm{t} 1)$ and upon arrival to the intensive care unit (t2). The sesamples were centrifuged at 3000 rpmfor 10 minutes and then stored at $-80{ }^{\circ} \mathrm{C}$ until analysis. Thiol disulfide hemostasis parameters were measure dusing the spectrophotometric method developed by Erel and Neselioglu using commercially available kits (Rel Assay Diagnostics, Turkey) (9).

From the measured total thiol and native thiol values; disulfid, disulfide / native thiol ratio, disulfide / total thiol ratio and native thiol / total thiol ratios were calculated.

\section{Statistical Analysis}

All statistical analyses were performed using the Statistical Package fort the Social Science (SPSS) software (SPSS, Microsoft Inc. an IBM Company, Chicago, USA) version 21.0. "Kolmogorov-Smirnov test and Shapiro-Wilk test" were used for normality distribution. While "Student's t test" was used for the data with normal distribution, "Mann-Whitney $U$ test" was used for the data that did not comply with the normal distribution. "Chi Square test" was used to compare nominal data. $P$ value below 0.05 was considered significant. Logistic regression analysis was performed for the appropriate variables in predicting AKI emerging after CABG surgery. Receiving operating characteristic (ROC) curve analysis was performed for postoperative disulfide and disuffid / total thiol, and the area under the curve (AUC) was calculated.

\section{RESULTS}

A total of 76 patients were included in the study and 19 (25\%) patients were found to develop postoperative AKI. Group 1 had 57 patients and their average age was 58.6 \pm 9 , while Group 2 had 19 patients and their average age was $61.7 \pm 8.2$. There was no difference between the groups in terms of age, gender, BMI, hyperlipidemia, HT, $\mathrm{DM}, \mathrm{COPD}$ and their current medical treatments (such as acetyl salicylic acid, angiotensin receptor blocker therapy). The time from coronary angiography to operation was significantly less in Group $2(P=0.037)$ (Table 1).

Table 1. Preoperative variables and demographic datas of the patients

\begin{tabular}{|c|c|c|c|}
\hline Characteristics & Group $1(n=57)$ & Group $2(n=19)$ & $P$ value \\
\hline Age (years) mean \pm sd & $58.6 \pm 9$ & $61.7 \pm 8.2$ & $0.180 \dagger$ \\
\hline Male gender, n(\%) & $40(70.1)$ & $11(57.8)$ & 0324 * \\
\hline Previous PCI, n(\%) & $15(26.3)$ & $6(31.5)$ & $0.758 *$ \\
\hline Hypertension, n(\%) & $24(42.1)$ & $7(36.8)$ & $0.685 *$ \\
\hline Hyperlipidemia, n (\%) & $25(43.8)$ & $9(57.8)$ & $0.593 *$ \\
\hline PAD, n (\%) & $7(12.2)$ & $3(15.7)$ & $0.894 *$ \\
\hline COPD, n (\%) & $8(14)$ & $5(26.3)$ & $0.427 *$ \\
\hline BMI (kg/m2) & $29.3 \pm 5.1$ & $30.7 \pm 6.8$ & $0.278+$ \\
\hline Diabetes mellitus, n (\%) & $20(35)$ & $8(42.1)$ & $0.585 *$ \\
\hline Smoking, n (\%) & $21(36.8)$ & $6(31.5)$ & $0.676 *$ \\
\hline Angiography to operation time, (days) & $3(2,85)$ & $3(2,30)$ & $0.037 \ddagger$ \\
\hline ASA use, $n(\%)$ & $50(87.7)$ & $16(84.2)$ & $0.812 *$ \\
\hline ACE-I/ ARB use, n(\%) & $19(33.3)$ & $5(26.3)$ & $0.447 *$ \\
\hline Ejection fraction (\%) & $50(35-65)$ & $50(30-60)$ & 0.554 \\
\hline EuroScore II & $1.8(0.5-4.8)$ & $2.1(0.5-5.2)$ & $0.077 \ddagger$ \\
\hline
\end{tabular}

Student's $t$ test, * Chi-square test, $¥$ Mann Whitney $U$ test (Data is expressed as median (interquartile range))ACE-I: Angiotensin-converting enzyme inhibitor, ARB: Angiotensin-receptor blocker, BMI: Body mass index, COPD: Chronic obstructive pulmonary disease, PCl: Percutaneus coronary intervention, PAD: Peripheral artery disease

Preoperative laboratory parameters data of the patients are given in Table 2. There was no difference between the groups in terms of hemogram parameters, C-reactive protein, albumin and thiol hemostasis parameters in the preoperative period. Preoperative creatinine values were significantly higher in Group $2(P=0.016)$. Parameter values of thiol-disulfid hemostasis obtained from the blood sample taken with in the first 2 hours at the entrance to intensive care after the operation of the patients are given in Table 3. There was no difference between the two groups in terms of native thiol, total thiol, disulfide / native thiol and native thiol / total thiol. In Group 2, disufide and disulfide / total thiol values were significantly higher $(P=$ $0.018, P=0.009$, respectively).

Other peroperative variables of the patients are given in Table 4. There was no difference between the groups in terms of distal anostomosis numbers, perfusion times, total postoperative drainage amounts, and time to postoperative extubation. Positive inotropic requirement rates, total amount of blood product used, intensive care and total hospital stay were significantly higher in Group 2 
Table 2. Preoperative laboratory values of the patients

Characteristics
Hemoglobin $(\mathrm{g} / \mathrm{dL})$
White blood cell $(103 / \mu \mathrm{L})$
Neutrophil $(103 / \mu \mathrm{L})$
Lymphocyte $(103 / \mu \mathrm{L})$
Creatinine $(\mathrm{mg} / \mathrm{dL})$
C Reactive protein $(\mathrm{mg} / \mathrm{dL})$
Albumin $(\mathrm{g} / \mathrm{L})$
Nativethiol $(\mu \mathrm{mol} / \mathrm{L})$
Total thiol $(\mu \mathrm{mol} / \mathrm{L})$
Disulfide $(\mu \mathrm{mol} / \mathrm{L})$
Disulfide/native thiol
Disulfide/total thiol
Native thiol/total thiol

$$
\begin{gathered}
\text { Group } 1(n=57) \\
13.5(12.8-15.7) \\
7.9(6.3-9.9) \\
4.2(3.3-8.1) \\
2.1(0.8-3.3) \\
0.8(0.3-1.42) \\
8.7(1.9-33.7) \\
39(35-50) \\
115.9(12.9-273) \\
186.1(53.3-490.2) \\
33.1(1.1-131.5) \\
29.4(0.6-165.1) \\
18.5(0.6-38.4) \\
63(23.2-98.7)
\end{gathered}
$$

$\begin{array}{cc}\text { Group 2 }(\mathbf{n}=19) & \text { p value } \\ 13.1(12.6-15.9) & 0.418 \ddagger \\ 8.1(6.4-10.7) & 0.554 \ddagger \\ 4.5(3.4-9) & 0.317 \ddagger \\ 1.9(0.7-3.2) & 0.259 \ddagger \\ 1.2(0.4-1.49) & 0.016 \ddagger \\ 9(2-35.2) & 0.610 \ddagger \\ 38.7(34.2-54) & 0.526 \ddagger \\ 137.8(31.9-245.3) & 0.278 \\ 208.4(104.7-465.6) & 0.305 \\ 35.8(10.4-110.2) & 0.102 \\ 35.4(5.9-114.1) & 0.976 \\ 19.7(5.3-34.8) & 0.271 \\ 58.6(30.5-89.4) & 0.981\end{array}$

†Student's $t$ test (Data is axpressed as mean $\pm s d)$, $\ddagger$ Mann Whitney $U$ test (Data is expressed as median (interquartile range)

Table 3. Admission to intensive care unit (t2) thiol-disulfide homeostasis parameters of the patients

$\begin{array}{lccr}\text { Characteristics } & \text { Group 1 }(\mathbf{n = 5 7}) & \text { Group 2 (n=19) } & \text { P value } \\ \text { Native thiol }(\boldsymbol{\mu m o l} / \mathrm{L}) & 134.2(15.5-359.8) & 131.8(84.5-275.3) & 0.606 \ddagger \\ \text { Total thiol }(\boldsymbol{\mu m o l} / \mathrm{L}) & 192(33.9-640.4) & 206.4(92.6-529.5) & 0.265 \ddagger \\ \text { Disulfide }(\boldsymbol{\mu m o l} / \mathrm{L}) & 26.7(0.9-160.1) & 37.6(4.1-172.7) & 0.018 \ddagger \\ \text { Disulfide/native thiol } & 19.7(0.6-104.1) & 27.4(4.6-69.8) & 0.181 \ddagger \\ \text { Disulfide/total thiol } & 14.8 \pm 7.9 & 19.4 \pm 7.1 & 0.009 \dagger \\ \text { Native thiol/total thiol } & 70.3 \pm 15.8 & 65.1 \pm 14.3 & 0.193 \dagger\end{array}$

†Student's $t$ test (Data is axpressed as mean $\pm s d)$ ) $\ddagger$ Mann Whitney $U$ test (Data is expressed as median (interquartile range),

Table 4. Peroperative variables of the patients

Characteristics
Distal anostomosis number
CCt (minutes)
TPt (minutes)
Total chest tube drainage (ml)
Packed blood products (units)
Inotropic support, $\mathbf{n}$ (\%)
Extubation time (hours)
ICU stay (days)
Total hospital stay (days)

Group $1(n=57)$
$3(1-5)$
$92.8 \pm 34.5$
$117.2 \pm 33.2$
$550(250-900)$
$5(4,12)$
$12(21)$
$6(3-9)$
$2.2 \pm 0.8$
$6.4 \pm 1.3$

Group $2(n=19)$
$3(1-5)$
$98.8 \pm 34.1$
$127.8 \pm 35.7$
$500(300-1100)$
$7(4,16)$
$11(57.8)$
$6(5-12)$
$3.8 \pm 1.3$
$8.3 \pm 1.4$

$P$ value $0.959 \ddagger$ $0.516+$ $0.242+$ $0.211 \ddagger$ $0.018 \ddagger$ $0.002 *$ $0.115 \ddagger$ $0.019+$ tStudent's $\mathrm{t}$ test (Data is axpressed as mean $\pm s d$ ), $\ddagger$ Mann Whitney U test (Data is expressed as median (interquartile range), 
( $P=0.002,0.018,0.019,0.011$, respectively).

Logistic regression analysis was performed to predict AKI after the operation (Table 5). Preoperative creatinine height (Odds Ratio [OR]: 1.234, 95\% Confidence interval [CI]: $1.090-1.578, P=0.030)$, less time to operation after angiography (OR:0.648, $\mathrm{Cl} 95 \%$ : $0.554-0.875, \mathrm{P}=0.041$ ), postoperative disulfide values (OR:0.718, $\mathrm{Cl}$ 95\%: 0.527 $0.894 \mathrm{P}=0.021)$, postoperative disulfide / total thiol ratio (OR:1.696, Cl 95\%: 1.472-1.987, P=0.013 ), total amount of blood product used (OR:1.012, Cl 95\%: 1.002-1.124, $\mathrm{P}=0.034$ ) and need for inotropic drugs (OR:1.334, Cl 95\%: 1.021-1.539, $\mathrm{P}=0.004)$ significant correlation with postoperative AKI was detected. In multivariate analysis, preoperative creatinine height (OR:1.079, Cl 95\%: 1.007$1.434, \mathrm{P}=0.039$ ), postoperative disulfide / total thiol ratio (OR:1.336, Cl 95\%: 1.090-1.834, $\mathrm{P}=0.021$ ) and inotropic drug need (OR:1.056, Cl 95\%: 1.009-1.318, $\mathrm{P}=0.019$ ) were determined as independent predictors for predicting postoperative AKI.

In the ROC analysis, cut-off values were 32.9 (AUC: 0.701 , $95 \% \mathrm{Cl}: 0.562-0.840 \mathrm{p}=0.009,73.7 \%$ sensitivity and $43.9 \%$ specificity) for postoperative disulfide, and 15.3 (AUC: $0.746,95 \% \mathrm{Cl}$ for postoperative disulfide / total thiol. (Cl:0.636-0.857, $\mathrm{p}=0.001,82.4 \%$ sensitivity and $51.9 \%$ specificity) (Figure 1).

Table 5. Logistic regression analysis to identify factors affecting postoperative acute kidney injury

\begin{tabular}{|c|c|c|c|c|c|c|}
\hline \multirow[b]{2}{*}{ Variables } & \multicolumn{3}{|c|}{ Univariate analysis } & \multicolumn{3}{|c|}{ Multivariate analysis } \\
\hline & $\mathbf{P}$ & Exp(B) Odds Ratio & 95\% C.I. Low-er Upper & $\mathbf{P}$ & Exp(B) Odds Ratio & 95\% C.I. Lower Upper \\
\hline Age & 0.212 & 0.789 & $0.529-2.140$ & -- & -- & -- \\
\hline Creatinine & 0.020 & 1.234 & $1.090-1.578$ & 0.039 & 1.079 & $1.007-1.434$ \\
\hline Angiography to operation time & 0.041 & 0.648 & $0.554-0.875$ & 0.214 & 1.002 & $0.897-1.202$ \\
\hline Disulfide (t2) & 0.021 & 0.718 & $0.527-0.894$ & 0.114 & 0.875 & $0.678-1.102$ \\
\hline Packed blood products & 0.034 & 1.012 & $1.002-1.124$ & 0.226 & 0.978 & $0.916-1.354$ \\
\hline Inotropic support & 0.004 & 1.334 & $1.021-1.539$ & 0.019 & 1.056 & $1.009-1.318$ \\
\hline CCt & 0.518 & 0.765 & $0.414-1.718$ & -- & -- & -- \\
\hline
\end{tabular}

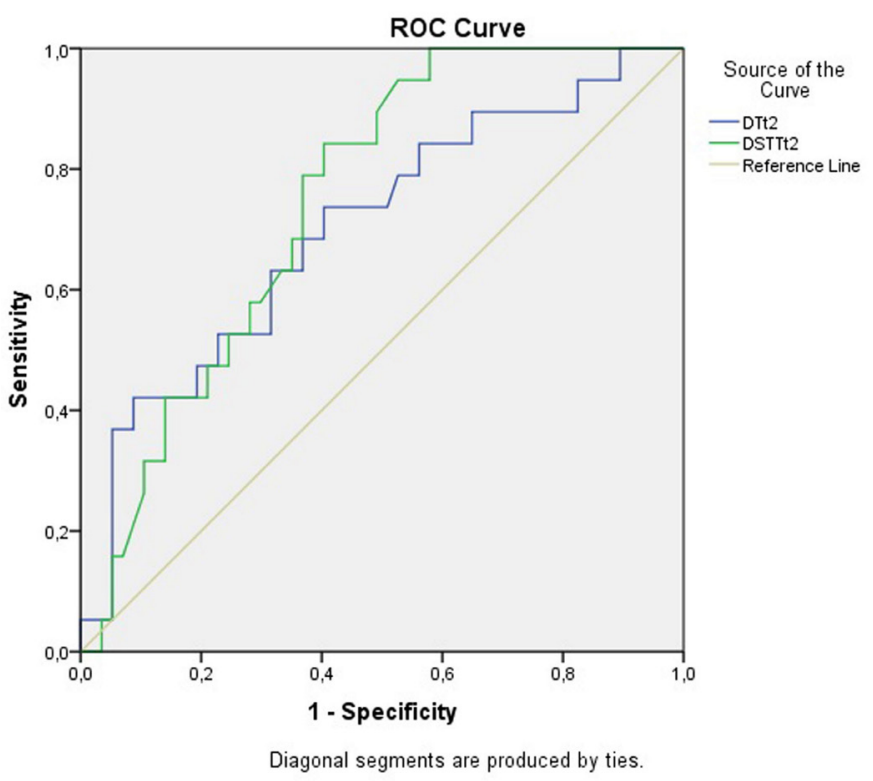

Figure 1. ROC (Receiver operation characteristic) curve and AUC (Are aunder the curve) for postcardiotomy Disulfide/total thiol (DSTTt2) and postcardiotomy Disulfide thiol (DTt2) for predicting postoperative acute kidney injury (DSTTt2: AUC: $0.746,95 \% \mathrm{Cl}$ : $0.636-0.857, p=0.001$, cut-off $=15.3,82.4 \%$ sensitivity and $51.9 \%$ specificity) (DTt2: AUC: $0.701,95 \% \mathrm{Cl}: 0.562-0.840 \mathrm{p}=0.009$, cutoff $=32.9,73.7 \%$ sensitivity and $43.9 \%$ specificity)

\section{DISCUSSION}

Today, open heart surgery is successfully used in the treatment of many cardiac diseases. In these surgeries, CPB systems are mostly used and one of the most important morbid results that can occur is postoperative AKI. The most important finding in this current study is that we determine that thiol-disulfid hemostasis values, which are among the new oxidative stres parameters, can be used to predict AKI after open heart surgery. In our multivariate analysis, we found that besides the disulfide / total thiolratio, preoperative creatinine height and inotropic drug use are independent predictors for predicting postoperative AKI.

Oxygen is an indispensable molecule for the human organism, and reactive oxygen radicals that occur during metabolic events are molecules that can be harmful. These reactive oxygen radicals are mostly composed of free radicals. There are antioxidant systems in our body to reduce the harmful effects of these free radicals. Organic compounds that contain a sulfhydryl (-SH) group are known as thiols to prevent any stress in our cells (10). The oxidation of these thiol groups leads to the formation of disulfide bonds (-SS). This dynamic equilibrium is a bidirectional reaction, known as thiol- 
disulfide hemostasis. This dynamic hemostasis balance plays an important role in antioxidant defense, apoptosis, detoxification and transmission of cellular signals (11).

Although it is also caused by the existing disease in open heart operations, the formation of oxidative stres becomes inevitable with the use of CPB systems. In a recent study, the relationship of thiol-disulfide hemostasis parameters with cross-clamp times and their effectiveness in predicting postoperative rhythm disorders were investigated in CABG-guided CABG operations (12). 51 patients were included in the study and blood samples were measured 3 times, preoperatively, immediately after the cross-clamp was removed, and at the postoperative sixth hour. The authors found that as a result of this study, increased crossclamp times and disulfide levels increased. In addition, in the multivaritae analysis, they stated that the disulfide / total thiol ratio observed after cross-clamp can be an independent predictor in predicting postoperative atrial fibrillation. In our study, although the number of patients was higher than this study, thiol-disulfide hemostasis parameters were evaluated at two different times as preoperative and postoperative 2 nd hour. As a result, we determined the postoperative disulfide / total thiol ratio as an independent predictor in predicting AKI, which is an undesirable morbid condition such as postoeprative atrial fibrillation.

In another study conducted by Ozgunay SE et al. (13), in cardiac surgery operations using the CPB system, they divided patients in to two groups as those who were continuously ventilated and those who were not ventilated during CPB. In this study, it has been shown that thiol-disulfide hemostasis may be an indicator of increased oxidative stress. Accordingly, the relationship of thiol-disulfide hemostasis with coronary artery disease was also investigated. In the study conducted by Altıparmak et al. (14), native thiol values were found low in patients with severe coronary artery disease. Similar findings were supported by the study by Kundi et al (6).

AKI may be after cardiac surgery or it may develop depending on the medication given to the other patients under treatment in the hospital and the disease itself. In a study conducted by Qian et al. (15) with 160 patients, the effects of thiol groups on in-hospital developing AKI were investigated. In this study, serum thiol values were found lower in patients with AKI than healthy volunteers. At the same time, the 90-day over all mortality rate was found to be higher in AKI patients with high serum protein thiol levels than those with low thiol levels. However, dynamic thiol-disulfide hemostasis was not evaluated in this study. According to our information in the results of our literature review, our study is one of the rare studies investigating $A K I$ after $C A B G$ surgery accompanied by CPB, and dynamic thiol-disulfide hemostasis parameters were measured. Another study investigating the relationship between $\mathrm{AKI}$ and thioldisulfide hemostasis was done by Korkmaz et al. (16).
In this study, which included a total of 302 patients, the location of oxidative parameters was investigated in predicting contrast nephropathy after coronary intervention in patients with myocardial infarction. In the multivariate analysis, the disulfide / total thiol ratio was determined as an independent predictor for contrast nephropathy. Gafney AM et al. (17) in his study, the main known risk factors for $A K I$ that occur after open heart operations; They reported the use of CPB systems, blood product use, inotropic agent use, age, hypertension, and the presence of preoperative renal failure. The use of positive inotropic agents can lead to renal ischemia due to vasoconstrictor effects.

Due to the use of blood products, hemolysis increases, and increased hemolysis metabolites can cause renal injury. In the study conducted by Ramos et al. (18), increased blood transfusion and inotropic agent use in predicting AKI after open heart surgery were shown as independent predictors of AKI. In our study, we concluded that the increase in blood and blood product transfusion and the use of inotropic agents play an effective role in the development of AKI in accordance with this study. There are also studies that the operation time after coronary angiography may affect postoperative AKI development.

In the study conducted by Del Duca et al. (19), it was shown that the operations performed in the first five days after coronary angiography may increase the postoperative AKI. In another study conducted by Ranucci et al. (20), it was found that the risk of AKI may increase 3 times in the operations performed in the first day after coronary angiography. In our study, we found that the shorter time until surgery after coronary angiography may correlate with the development of AKI.

Our study has limitation ssuch as being single-centered, performing operations with more than one surgical team, and limited number of patients.

\section{CONCLUSION}

As a result; we believe that the values of disulfide and disulfide / total thiol ratio, which are among the thioldisulfide hemostasis parameters, in the postoperative period may be predictors for AKI. We believe that multicentre studies with large patient groups are needed to support these results.

Financial disclosures: All authors report no financial interests or potential conflicts of interest.

Conflict of Interest: The authors declare that they have no competing interest.

Acknowledgments: The authors declare that there is no conflict of interest associated with this study.

Ethical approval: The study was approved by the local ethics committee (HRU / 25.02.2019)

\section{REFERENCES}

1. Pickering JW, James MT, Palmer SC. Acute kidney injury and prognosis after cardiopulmonary bypass: a meta-analysis 
of cohort studies. Am J Kidney Dis 2015; 65:283-93.

2. De Santo LS, Romano G, Mango E, et al. Age and blood transfusion: relationship and prognostic implications in cardiac surgery. J Thorac Dis 2017;9:3719-27.

3. Jyrala A, Weiss RE, Jeffries RA, et al. Effect of mild renal dysfunction (s-crea 1,2-2,2 $\mathrm{mg} / \mathrm{dl}$ ) on presentation characteristics and short- and long-term outcomes of onpump cardiac surgery patients. Interact Cardiovasc Thorac Surg 2010;10:777-82.

4. Arthur JM, Hill EG, Alge JL, et al. SAKInet Investigators. Evaluation of 32 urine biomarkers to predict the progression of acute kidney injury after cardiac surgery. Kidney Int 2014;85:431-8.

5. Parlar $H$, Saskın $H$. Are pre and postoperative platelet to lymphocyte ratioand neutrophilto lymphocyte ratio associated with early postoperative AKI Following CABG? Braz J Cardiovasc Surg 2018;33:233-241.

6. Kundi H, Ates I, Kiziltunc E, et al. A novel oxidative stress marker in acute myocardial infarction; thiol/ disulphide homeostasis. Am J Emerg Med 2015;33:1567-71.

7. Ayar G, Sahin S, Yazici MU, et al. Effects of hemodialysis on thiol-disulphide homeostasis in critically ill pediatric patients with acute kidney injury. Biomed Res Int 2018;2018:1898671.

8. Lopes JA, Fernandes P, Jorge S, et al. Acute kidney injury in intensive care unit patients: a comparison between the RIFLE and the Acute Kidney Injury Network classifications. Crit Care 2008;12: R110.

9. Erel O, Neselioglu S. A novel and automated assay for thiol/ disulfide homeostasis. Clin Biochem 2014;47:326-32.

10. Sen CK, Packer L. Thiol homeostasis and supplements in physical exercise. Am J Clin Nutr 2000;72:653-69.

11. Gumusyayla S, Vural G, Bektas H, et al. A novel oxidative stress marker in patients with Alzheimer's disease: dynamic thiol-disulphide homeostasis. Acta Neuropsychiatr 2016; 28:315-20.
12. Sanri US, Özsin KK, Toktas F, et al. The effect of thioldisulfide homeostasis in patients undergoing on-pump coronary artery bypass grafting. Turk Gogus Kalp Damar 2019;27:484-92.

13. Ozgunay SE, Ozsin KK, Ustundag $Y$, et al. The effect of continuous ventilation on thiol-disulphide homeostasis and albumin adjusted ischemia-modifed albumin during cardiopulmonary bypass. Braz J Cardiovasc Surg 2019;34:436-43

14. Altiparmak $\mathrm{IH}$, Erkus $\mathrm{ME}$, Sezen $\mathrm{H}$, et al. The relation of serum thiol levels and thiol/disulphide homeostasis with the severity of coronary artery disease. Kardiol Pol 2016;74:1346-53

15. Qian X, Fang J, Zhu Q, et al. Serum protein thiol levels in patients with hospital-acquired acute kidney injury. Kidney Blood Press Res 2015;40:623-9.

16. Korkmaz A, Ozyazgan B, Kosem A, et al. The role of thiol levels in predicting contrast-induced nephropathy in patients with ST-segment elevation myocardial infarction who underwent primary percutaneous coronary intervention. North Clin Istanb 2019;6:210-8.

17. Gaffney AM, Sladen RN. Acute kidney injury in cardiac surgery. Curr Opin Anaesthesiol 2015;28:50-9.

18. Ramos KA, Dias CB. Acute kidney injury after cardiac surgery in patients without chronic kidney disease. Braz J Cardiovasc Surg 2018; 33:454-61.

19. Del Duca D, Iqbal S, Rahme E, et al. Renal failure after cardiac surgery: timing of cardiac catheterization and other perioperative risk factors. Ann Thorac Surg 2007;84:126471.

20. Ranucci M, Ballotta A, Agnelli B, et al. Acute kidney injury in patients undergoing cardiac surgery and coronary angiography on the same day. Ann Thorac Surg 2013;95:5139. 